\title{
Editorial: Bringing light into deep-sea biodiversity*
}

\author{
PEDRO MARTÍNEZ ARBIZU ${ }^{1} \&$ SASKIA BRIX ${ }^{2}$ \\ ${ }^{\prime}$ German Centre for Marine Biodiversity Research (DZMB), Senckenberg Research Institute, Südstrand 44, 26382 Wilhelmshaven, \\ Germany; pmartinez@senckenberg.de \\ ${ }^{2}$ German Centre for Marine Biodiversity Research (DZMB), Senckenberg Research Institute, clo Biocentrum Grindel, Martin-Luther- \\ King-Platz 3, 20146 Hamburg, Germany; sbrix@senckenberg.de
}

*In: Martínez Arbizu, P. \& Brix, S. (Eds) (2008) Bringing Light into Deep-sea Biodiversity. Zootaxa, 1866, 1-574.

Despite the fact that oceans cover over $70 \%$ of the earth's surface, only about one third of all currently known species have been described from marine ecosystems (Reaka-Kudla 1997, Groombridge \& Jenkins 2000, Grassle 2001, Boltovskoy et al. 2005). We believe that this represents an underestimation of the real biodiversity in the oceans (Bouchet 2006). Since the year 2000, the "Census of Marine Life" (CoML, www.coml.org), an international initiative involving more than 2000 researchers from 80 nations, is putting a huge effort into describing and understanding patterns of species richness and distribution in all ocean realms. The deep sea is one of the largest ecosystems on earth and probably harbours a substantial amount of biodiversity. The fraction of new species to be found in deep-sea areas visited for the first time ranges from 50 to $100 \%$ (Wilson 1980, Poore et al. 1994, Park 2000, Brandt et al. 2004, Brandt et al. 2007a,b), with most of them only being represented by single individuals in the samples (Rose et al. 2005, Brandt et al 2007a,b,). This fact, together with the logistic impediments of sampling in abyssal plains, constrains our knowledge of the life in the hidden depths of the ocean.

The Census of the Diversity of Abyssal Marine Life (CeDAMar, www.cedamar.org) is devoted to the study of latitudinal gradients of diversity in abyssal plains. To accomplish this task, various expeditions collecting organisms of all size classes from bacteria to megafauna took place in the South Atlantic, the Pacific, the Southern Ocean and the Mediterranean Sea, all using the same methodologies. CeDAMar recognizes the importance of accurate species descriptions for ecological studies like diversity comparisons, biogeography or community structure analysis. With as many as $90 \%$ of the earth's species undescribed, the vision of a resolved phylogeny of life may be compromised unless there is an ambitious effort in order to advance descriptive taxonomy as the base of phylogenetic systematics (Wheeler 2004, 2007). Therefore, one of CeDAMar most ambitious goals is to promote the description of 500 new abyssal species by 2010 . The present special volume of Zootaxa devoted to deep-sea biodiversity contributes to this goal with 44 new species descriptions, descriptions of five new genera and several redescriptions.

These descriptions cover various groups including crustaceans: Copepoda (Calanoida, Harpacticoida and Siphonostomatoida), Isopoda (Serolidae and four asellote families) and Ostracoda, furthermore: Nematoda, Brachiopoda, Mollusca (Gastropoda, Solenogastres, Poly- and Monoplacophora) and Porifera (Hexactinellida, Poecilosclerida, Polymastiidae and Suberitidae). The material described in this volume was inter alia collected during several CeDAMar expeditions investigating unexplored areas of the world's ocean, for example with RV Meteor (Martínez Arbizu \& Schminke 2005) and RV Polarstern (Brandt \& Hilbig 2004, 2007). Furthermore, material was collected during different Australian and New Zealand cruises and in the Pacific region. 
Part of the descriptions presented in this volume were initiated during several CeDAMar workshops, e.g. during the workshop on peracarid crustaceans in Wilhelmshaven 2005, on nematods in Ghent 2007, polychaetes in London 2007 or isopod taxonomy in March 2007 held at the German Centre for marine Biodiversity Research (DZMB) in Wilhelmshaven. We hope that this volume will bring some "light" into the "dark" deep sea by enhancing our knowledge about what lives down there.

The CeDAMar project benefits from a generous grant of the Alfred Sloan Foundation, without which this special volume would never have been possible. We specially acknowledge the Census of Marine Life scientific steering group and secretariat for continuous advice and support.

\section{References}

Brandt, A. \& Hilbig, B. (Guest Eds.) (2004) Topical Studies in Oceanography. ANDEEP (ANtarctic benthic DEEP-sea biodiversity: colonization history and recent community patterns) - a tribute to Howard L. Sanders. Deep-Sea Research II 51, pp. 1457-1919.

Brandt, A. \& Ebbe, B. (Guest Eds.) (2007) Topical Studies in Oceanography. ANtarctic benthic DEEP-sea biodiversity: colonization history and recent community patterns (ANDEEP III). Deep-Sea Research II 54, pp. 1645-1904

Brandt, A., Brökeland, W., Brix, S. \& Malyutina, M. (2004) Diversity of Southern Ocean deep-sea Isopoda (Crustacea, Malacostraca) - a comparison with shelf data. Deep-Sea Research II. Vol. 51, 1753-1768.

Brandt, A., Brix, S., Brökeland, W., Cedhagen, T., Choudury, M., Cornelius,N., Danis, B., De Mesel, I., Diaz, R.J., Gillan, D.C., Hilbig, B., Howe, J., Janussen, D., Kaiser, S., Linse, K., Malyutina, M., Brandao, S., Pawlowski, J., Raupach, M. \& Gooday, A.J. (2007) The Southern Ocean deep sea: first insights into biodiversity and biogeography. Nature, pp. 307-311.

Brandt, A., Brix, S., Brökeland, W., Choudury, M., Kaiser, S. \& Malyutina, M. (2007) Deep-sea isopod biodiversity, abundance, and endemism in the Atlantic sector of the Southern Ocean - Results from the ANDEEP I-III expeditions, Deep-Sea Research II 54, pp. 1760-1775

Bouchet, P. (2006) The magnitude of marine biodiversity. In: Duarte, C. (Eds.) The exploration of marine biodiversity: scientific and technological challenges. pp. 31-62

Boltovskoy, D., Correa, N. \& Boltovskoy, A. (2005) Diversity and Endemism in cold Waters of the South Atlantic: contrasting patterns in the plankton and the benthos. Scientia Marina 69 (Suppl. 2), pp. 17-26.

Grassle, J.F. (2001) Marine Ecosystems. In: Levin, S.A. (Eds.), Encyclopaedia of Biodiversity, San Diego: Academic Press, pp. 13-25.

Groombridge, B. \& Jenkins, M.D. (Eds.) Global biodiversity: Earth's living resources in the 21st century. Cambridge: World Conservation Press. 340 pp.

Martínez Arbizu, P. \& Schminke, K. (Eds.) Organisms, Diversity and Evolution. 5 (2005) Supplement 1. pp. 1-238.

Park, J.Y. (2000) Taxonomy and Diversity of the Deep-Sea Isopods from the Abyssal Southeast Pacific (Crust., Isop., Asellota): A Study of Environmental Impact on the Deep-Sea Isopod Community, Resulting from a Large-Scale Physical Disturbance Experiment in the Peru Basin, Ph.D. thesis, University of Bielefeld, Germany.

Poore, G.C.B.; Just, J.; Cohen, B.F. (1994) Composition and Diversity of Crustacea (Isopoda) of the Southern Australian Continental Slope. Deep Sea Research I 41 (4), pp. 677-693.

Reaka-Kudla, M.L. (1997) The global biodiversity of coral reefs: a comparison with rain forests, in M. L. Reaka-Kudla, D. E. Wilson and E. O. Wilson, eds. Biodiversity II. Washington, Joseph Henry Press, pp. 83-108.

Rose, A. Seifried, S., Willen, E., George, K. H., Veit-Khler, G., Brhldick, K., Drewes, J., Moura, G., Martnez Arbizu, P. \& H. K. Schminke (2005) A method for comparing within-core alpha diversity values from repeated multicorer samplings, shown for abyssal Harpacticoida (Crustacea: Copepoda) from the Angola Basin. Organisms Diversity and Evolution 5 (Suppl. 1), pp. 3-17.

Wheeler, Q.D. (2004) Taxonomic Triage and the Poverty of Phylogeny. Philosophic Transactions of the Royal Society, (359), 571-583.

Wheeler, Q.D. (2007) Invertebrate systematics or spineless taxonomy? In: Zhang, Z.-Q. \& Shear, W.A. (Eds) (2007) Linnaeus Tercentenary: Progress in Invertebrate Taxonomy. Zootaxa, 1668, 11-18.

Wilson, G.D. (1980) New Insights into the Colonization of the Deep Sea. Systematics and Zoogeography of the Munnidae and the Pleurogoniidae comb. nov. (Isopoda; Janiroidea). Journal of Natural History, 14, 215-236. 